\title{
Cadmium-Binding Capacity of a Soybean Protein Fraction
}

(Received April 25, 1985)

\author{
Seisaku Yoshida, Ryoichi TANAKa and Takashi KaSHIMoto*1
}

(Osaka Prefectural Institute of Public Health: 3-69, Nakamichi, 1-chome, Higashinari-ku, Osaka, Japan)

\begin{abstract}
The cadmium-binding capacity of the soybean protein fraction was determined by equilibrium dialysis. The aqueous supernatant was extracted from the soybeans with $0.01 M$ Trishydrochloric acid buffer ( $\mathrm{pH} \mathrm{7.4)}$ by ultracentrifugation. The protein fraction (F-I, $>10,000$ in molecular weight) was separated from the extract by Sephadex G-50 chromatography. Binding measurement was carried out in $0.01 M$ Tris-hydrochloric acid buffer ( $\mathrm{pH} \mathrm{7.4).} \mathrm{The} \mathrm{binding} \mathrm{data}$ were analyzed according to the Scatchard equation. A Scatchard plot of the binding data showed several phases, indicating heterogeneity of the binding sites. The maximum amount of cadmium bound by F-I was calculated to be $43,000 \mu \mathrm{g} / \mathrm{g}$. When cadmium was added to the aqueous supernatant, five cadmium-binding fractions (at molecular weights of $>100,000,75,000$, 38,000 , and two low-molecular species) were detected by chromatography on Sephadex G-100. The major cadmium-binding fraction in F-I was the macromolecular species of $>100,000$ in molecular weight.
\end{abstract}

Key words: soybeans; soybean proteins; cadmium; cadmium binding capacity; equilibrium dialysis; Scatchard equation; gel filtration

\section{Introduction}

Soybeans are a very important foodstuff since they provide both protein and minerals. Soybeans contain large amounts of heavy metals. We obtained high-level-cadmium(Cd)-containing soybeans from a Cd-polluted field. The molecular distributions of $\mathrm{Cd}$, copper $(\mathrm{Cu})$ and zinc $(\mathrm{Zn})$ in the aqueous supernatant of these soybeans were reported previously ${ }^{1) \sim 5}$. As regards the binding of heavy metals by soybean protein, we have reported the Cu-binding capacity of the unfractionated protein from these soybeans ${ }^{3)}$. The maximum amount of $\mathrm{Cu}$ bound by the unfractionated soybean protein was evaluated as $6,000 \mu \mathrm{g} / \mathrm{g}$ by equilibrium dialysis. Soybean protein can also bind larger amounts of $\mathrm{Cd}$ and $\mathrm{Zn}$. The amounts of $\mathrm{Cd}$ bound by glycinin were found to be larger than those by ovalbumin, gelatin and $\beta$-lactoglobulin ${ }^{8)}$. Binding of $\mathrm{Zn}$ (II)

*1 Present address; Department of Pharmacology, Setsunan University: 45-1, Nagaotoge-cho, Hirakata, Osaka, Japan by $11 \mathrm{~S}$ and $7 \mathrm{~S}$ fractions was reported to occur possibly through the imidazole groups of histidine residues ${ }^{7), 8}$. We report here on the estimation of the Cd-binding capacity of the soybean protein fraction by equilibrium dialysis. A very high Cd-binding capacity of the protein fraction was found by analysis of the binding data according to the Scatchard equation.

\section{Materials and Methods}

\section{Plant material}

The soybeans were obtained from Toyama prefecture, Japan. The heavy metals constituents in the soybeans were as follows: $\mathrm{Cd}, 1.4$ $\mu \mathrm{g} / \mathrm{g} ; \mathrm{Cu}, 14.9 \mu \mathrm{g} / \mathrm{g} ; \mathrm{Zn}, 103 \mu \mathrm{g} / \mathrm{g}$. The Cd level was ten times the background level ${ }^{8)}$, and the $\mathrm{Zn}$ content was nearly twice the background. $\mathrm{Cu}$ content was the same as the background.

\section{Reagents}

Tris(hydroxymethyl)aminomethane, cadmium chloride and the standard solutions for heavy metal analysis were obtained from Wako Pure Chemical Industries. Visking tubing (8/32) was 
used for dialysis. Sephadex from Pharmacia Fine Chemicals was used for the gel filtration. Standard proteins for use as molecular weight standards (bovine serum albumin, mol. wt. 67,000 ; ovalbumin, mol. wt. 43,000; chymotrypsinogen A, mol. wt. 25,000; ribonuclease A, mol. wt. 13,700; bacitracin, mol. wt. 1,400) were from Sigma and Pharmacia. All other chemicals were of reagent grade or better.

\section{Extraction and gel filtration}

The aqueous supernatant from the soybeans was prepared according to the previous paper ${ }^{4}$. The soybeans were homogenized with a highspeed blender after being soaked overnight in ten volumes of $0.01 M$ Tris-hydrochloric acid buffer ( $\mathrm{pH}$ 7.4). The supernatant was separated from the lipid layer and the residues by ultracentrifugation at $105,000 \mathrm{~g}$ for $60 \mathrm{~min}$ using a Hitachi Model 55P-2. The heavy metals contents in the extract were as follows: Cd, $2.9 \mu \mathrm{g} / \mathrm{g}$; $\mathrm{Cu} 30.3 \mu \mathrm{g} / \mathrm{g} ; \mathrm{Zn}, 119 \mu \mathrm{g} / \mathrm{g}$. The protein fraction (F-I) was separated from the extract by gel filtration on Sephadex G-50 using a $2.6 \times 35 \mathrm{~cm}$ column equilibrated with $0.01 M$ Tris-hydrochloric acid buffer ( $\mathrm{pH}$ 7.4). F-I was pooled, desalted on a Sephadex G-25 column and lyophilized. The heavy metals constituents of F-I were as follows: $\mathrm{Cd}, 4.5 \mu \mathrm{g} / \mathrm{g} ; \mathrm{Cu}, 17.3 \mu \mathrm{g} / \mathrm{g} ; \mathrm{Zn}, 132$ $\mu \mathrm{g} / \mathrm{g}$.

After the addition of $\mathrm{Cd}$, the aqueous supernatant was chromatographed on a $2 \times 92 \mathrm{~cm}$ Sephadex G-100 column with the buffer at a flow rate of $15 \mathrm{ml} / \mathrm{hr}$. The fraction size was $3.75 \mathrm{ml}$. The column had previously been calibrated with the molecular weight markers. The absorbance at $280 \mathrm{~nm}$ of the effluent was measured in a flow cell.

\section{Equilibrium dialysis}

F-I was dissolved in the buffer to give a concentration of $0.1 \mathrm{mg} / \mathrm{ml}$ or $1.0 \mathrm{mg} / \mathrm{ml}$. The protein solutions $(1 \mathrm{ml})$ were packed into dialysis tubing and then dialyzed for 6 hours against $100 \mathrm{ml}$ of the buffer containing various concentrations of $\mathrm{Cd}$ (in the form of cadmium chloride). Then the $\mathrm{Cd}$ concentrations of the inner protein solutions and the outer medium were measured. The amounts of $\mathrm{Cd}$ bound by the proteins were calculated from the difference in the $\mathrm{Cd}$ concentrations.

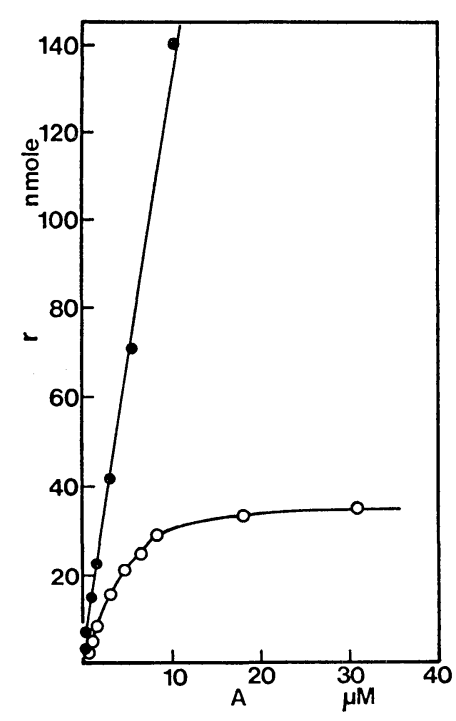

TFig. 1. Cd-binding equilibrium curves of F-I

F-I (๑: $1.0 \mathrm{mg} / \mathrm{ml}, \bigcirc: 0.1 \mathrm{mg} / \mathrm{ml}$ ) was dissolved in $0.01 M$ tris-hydrochloric acid buffer ( $\mathrm{pH} 7.4)$. The protein solutions $(1 \mathrm{ml})$ were dialyzed for $6 \mathrm{hr}$ against $100 \mathrm{ml}$ of the same buffer containing various concentrations of $\mathrm{Cd}$.

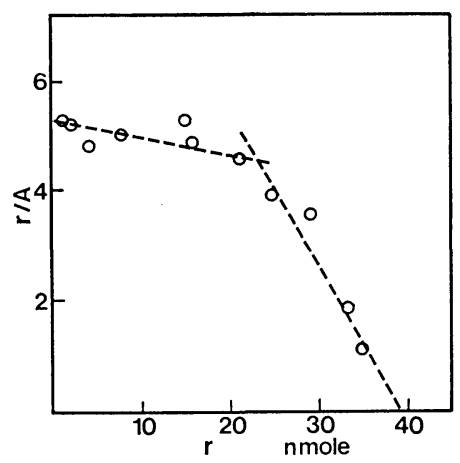

Fig. 2. Scatchard plot of the binding of $\mathrm{Cd}$ by F-I

Dotted lines are least-squares lines

\section{Metals analysis}

Metals were measured by atomic absorption spectrometry using a Nippon Jarrell-Ash Model AA 781. The eluate from the gel filtration column was measured directly, whereas plant materials were first ashed in a low temperature asher (International Plasma Corporation, Model $1101 \mathrm{~B})^{10)}$. 


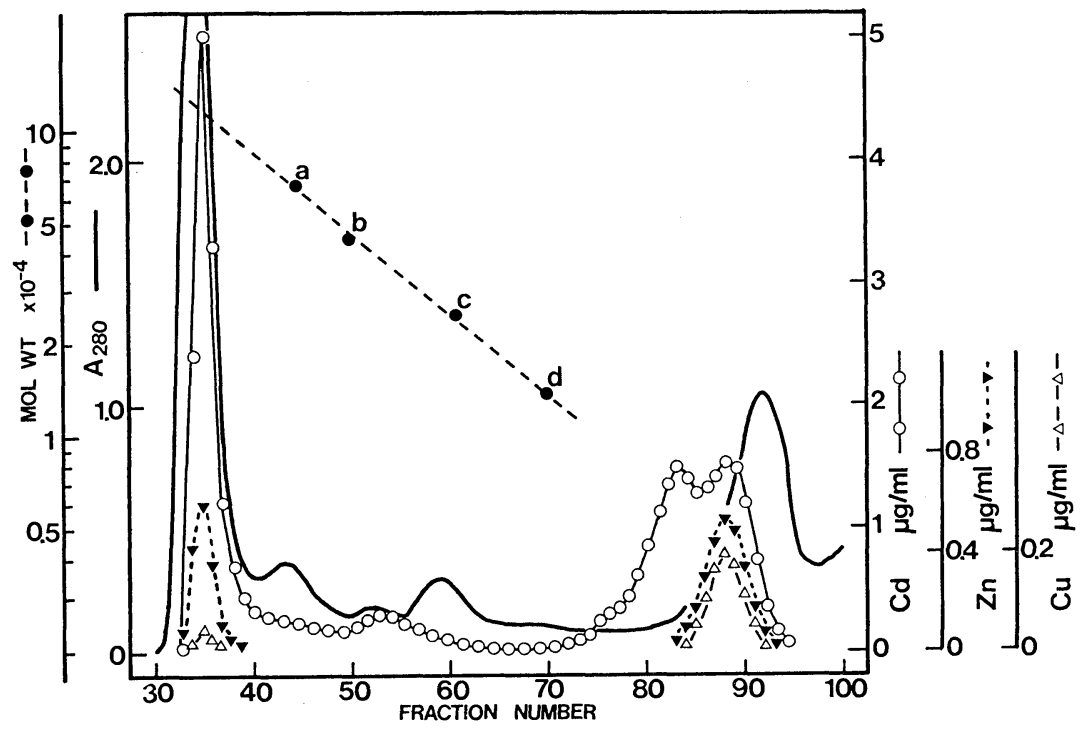

Fig. 3. Sephadex G-100 elution profile of Cd exogenously added to the aqueous soybean supernatant

The column $(2 \times 92 \mathrm{~cm})$ was equilibrated with $0.01 M$ tris-hydrochloric acid buffer (pH 7.4) and eluted with the same buffer at a flow rate of $15 \mathrm{ml} / \mathrm{hr}$. The fraction size was $3.75 \mathrm{ml}$. $200 \mu \mathrm{g}$ of $\mathrm{Cd}$ was added to $200 \mathrm{mg}$ of the aqueous soybean supernatant. The elution positions of standard proteins are indicated as follows: $a$, BSA; b, ovalbumin; c, chymotrypsinogen; d, ribonuclease. They are plotted versus the log of molecular weight.

\section{Results}

Cd-binding equilibrium curves of F-I measured by equilibrium dialysis are shown in Fig. $1 ; \mathrm{r}$, the number of $\mathrm{Cd}$ ions bound by $\mathrm{F}-\mathrm{I}$, is plotted versus the free $\mathrm{Cd}$ concentration, $\mathrm{A}$. The curve of F-I at $1.0 \mathrm{mg} / \mathrm{ml}$ showed a rapid increase in the amount of bound $\mathrm{Cd}$ even at a low concentration of $\mathrm{Cd}$ in the outer medium. A further increase was observed at higher free Cd concentration (over $10 \mu \mathrm{M}$ ). The Cd-binding equilibrium curve of F-I at $0.1 \mathrm{mg} / \mathrm{ml}$ showed a linear increase in the amount of $\mathrm{Cd}$ bound by F-I at a low free Cd concentration of about $<5 \mu M$, but the rate of increase in the amount of bound $\mathrm{Cd}$ decreased with increase in the $\mathrm{Cd}$ concentration of the outer medium. The curve became nearly flat at $20 \mu M$ to $30 \mu M$ free $\mathrm{Cd}$ concentration.

The binding data were analyzed according to the Scatchard equation to evaluate the dissociation constant, $\mathrm{Kd}$, and the maximum binding number of Cd by F-I, $n$. The equation is $r / A=$ $(n-r) / K d$. The Scatchard plot of the Cd-binding equilibrium curve of F-I $(0.1 \mathrm{mg} / \mathrm{ml})$ showed two or more phases, indicating heterogeneity of the binding sites (Fig. 2). Two least-squares lines are drawn in Fig. 2. The initial linear portion gave $\mathrm{Kd} 3.1 \times 10^{-5} M$ and the second linear portion gave $\mathrm{Kd} 3.3 \times 10^{-6} M$. The maximum binding number of $\mathrm{Cd}$ (the intercept of the straight line on the abscissa) was 39 corresponding to $43,000 \mu \mathrm{g} \mathrm{Cd}$ per $1 \mathrm{~g}$ F-I.

$\mathrm{Cd}$ was added exogenously to the aqueous supernatant and the mixture was chromatographed on a Sephadex G-100 column (Fig. 3). Five regions of Cd-content increase were observed. Three regions were found in the protein fractions and their molecular weights were calculated as $>100,000,75,000$ and 38,000 , respectively. The other two Cd-binding components were low-molecular compounds. The largest proportion of the bound $\mathrm{Cd}$ was present in the fraction of $>100,000 \mathrm{~mol}$ wt (38\% of the total Cd bound; $72 \%$ of the Cd bound by proteins). The lowest-molecular bound $\mathrm{Cd}$ was eluted with 
$\mathrm{Cu}$ and $\mathrm{Zn}$ in the fraction of $<1,000 \mathrm{in} \mathrm{mol} \mathrm{wt}^{5)}$.

\section{Discussion}

Soybean proteins were shown to have a very high Cd-binding capacity by equilibrium dialysis. The maximum amount of $\mathrm{Cd}$ bound by F-I was calculated to be $43,000 \mu \mathrm{g} / \mathrm{g}(4.3 \%)$ by analysis of the binding data according to the Scatchard equation. This was 30,000 times the initial $\mathrm{Cd}$ content of the sample soybeans $(1.4 \mu \mathrm{g} / \mathrm{g})$ and 10,000 times the Cd content of F-I $(4.5 \mu \mathrm{g} / \mathrm{g})$. The maximum binding amount of $\mathrm{Cu}$ by $\mathrm{F}-\mathrm{I}$ was $6,000 \mu \mathrm{g} / \mathrm{g}$, as reported previously ${ }^{3)}$. The maximum amount of $\mathrm{Cd}$ bound by F-I was one order higher than that of $\mathrm{Cu}$.

Appu Rao and Narasinga $\mathrm{Rao}^{7), 8)}$ reported that the maximum binding number of $\mathrm{Zn}$ (II) to $100,000 \mathrm{~g}$ of $11 \mathrm{~S}$ fraction was $17-18$, and that to $100,000 \mathrm{~g}$ of $7 \mathrm{~S}$ fraction was 7 . From our results, the maximum binding number of $\mathrm{Cd}$ to $100,000 \mathrm{~g}$ of F-I was 39 , i.e., more than twice that of $\mathrm{Zn}$ to $11 \mathrm{~S}$ or $7 \mathrm{~S}$ protein. If the molecular weight of F-I is assumed to be 200,000 , the maximum binding of Cd by 1 mole of F-I is calculated to be 78 mole. Appu Rao and Narasinga Rao suggested that the binding of $\mathrm{Zn}, \mathrm{Ca}$ and $\mathrm{Mg}$ by $11 \mathrm{~S}$ and $7 \mathrm{~S}$ protein of soybeans may occur through the imidazole groups of histidine residues on the basis of the total number of binding sites estimated from a Scatchard plot of the equilibrium dialysis data. The probable binding sites of $\mathrm{Cd}$ could not be identified on the basis of the results of this experiment. Some other binding sites for $\mathrm{Cd}$ besides the histidine residues may present in F-I.

When $\mathrm{Cd}(200 \mu \mathrm{g})$ was added exogenously to the aqueous supernatant $(200 \mathrm{mg})$, almost all the $\mathrm{Cd}$ added was bound by the extract. Half the bound $\mathrm{Cd}$ was found in the protein fractions and half was associated with low-molecular species. Most of the $\mathrm{Cd}$ bound by proteins was associated with macromolecules of $>100,000$ in mol wt, including $7 \mathrm{~S}$ and $11 \mathrm{~S}$ globulins and larger molecules. When $\mathrm{Cd}(100 \mu \mathrm{g})$ was added similarly

\footnotetext{
*1 Yoshida, S., Tanaka, R., Kashimoto, T.: proceedings of the 47th meeting of the Food Hyg. Soc. Japan in 1984, in Tokyo, p. 13.

*2 submitted for publication
}

to F-I $(100 \mathrm{mg})$, almost all the added $\mathrm{Cd}$ was bound; $24 \%$ of the bound $\mathrm{Cd}$ was associated with the molecules of $>100,000$ in mol wt and $40 \%$ was eluted in the region of fraction numbers 80 to 85 , as shown in Fig. 3. These fractions contained many phosphorus-containing materials, and they were considered to be phytate*1. The lowest-molecular bound $\mathrm{Cd}$ was eluted together with $\mathrm{Cu}$ and $\mathrm{Zn}$. The ligand of $\mathrm{Cd}$ might possibly be the same as that of $\mathrm{Cu}$ and $\mathrm{Zn}$. However, for determination of the ligand for Cd further gel filtration on Sephadex G-25 or G-10, or an ion exchange column, seems necessary.

A Cd-binding protein of about $10,000 \mathrm{~mol} \mathrm{wt}$ has been isolated from the soybean protein fraction of $>100,000 \mathrm{~mol}$ wt by treatment with a sulfhydryl reductant*2. The characterization of this component, including the Cd-binding capacity, is in progress. If both $\mathrm{Cd}$ and the soybean water-soluble fraction were taken simultaneously, soybean proteins and other components would be expected to bind $\mathrm{Cd}$ nonspecifically. It would be interesting to know what kind of chemical forms those Cd-complexes take in the gastrointestinal tract, and to know how the toxicity of $\mathrm{Cd}$ is affected.

\section{References}

1) Tanaka, R., Yoshida, S., Kashimoto, T.: J. Food Hyg. Soc. Japan 21, $243 \sim 246$ (1980).

2) Yoshida, S., Tanaka, R., Kashimoto, T.: ibid. 21, 247 251 (1980).

3) Yoshida, S., Tanaka, R., Kashimoto, T.: ibid. 23, 53 58 (1982).

4) Yoshida, S., Tanaka, R., Kashimoto, T.: ibid. 23, 319 324 (1982).

5) Yoshida, S., Tanaka, R., Kashimoto, T.: ibid. 24, 550 557 (1983).

6) Kojima, S., Kiyozumi, M., Kamiya, M., Ishimatsu, Y.: Eisei Kagaku, 25, $245 \sim 250$ (1979).

7) Appu Rao, A. G., Narasinga Rao, M. S.: J. Agric. Food Chem. 24, 487 490 (1976).

8) Appu Rao, A. G., Narasinga Rao, M. S.: ibid. 24, 490 494 (1976).

9) Tanaka, R., Ikebe, K., Tanaka, Y., Kunita, N.: J. Food Hyg. Soc. Japan 24, 488 499 (1983).

10) Tanaka, R., Ikebe, K., Kashimoto, T.: ibid. 24, 136 141 (1983). 